ISSN: 2362-1303 (Paper) | eISSN: 2362-1311(Online)

JOURNAL OF ADVANCED ACADEMIC RESEARCH (JAAR)

July 2015

\title{
Study of Credit Risk Identification Techniques Followed by Commercial Banks in Nepal
}

\author{
Indra Kumar Kattel ${ }^{1}$ \\ ${ }^{1} \mathrm{PhD}$ Scholar, Mewar University, Rajasthan, India \\ indra.kattel@rbb.com.np
}

ABSTRACT

The main purpose of this study is to explore the current credit risk identification techniques used by Nepalese commercial banks. A questionnaire was developed and surveyed to 9 commercial banks operating in Nepal. This paper attempts to ascertain the perceptions of Nepalese bankers about the importance of credit identification techniques and the practice of various tools to identify the risk related with the borrowers. The result of the study indicates that the Nepalese bankers are aware of the importance of various techniques to effectively identify the risk level. Furthermore, the Nepalese commercial banks have used various techniques like interview, root cause effect, check list analysis, Strength, Weakness, Opportunity and Threat (SWOT) analysis, scenario analysis, expert judgment, simulation, stress testing etc. In addition, there was significant difference between all three categories of bank, namely State-Owned bank with Private Bank, State-Owned bank with Joint Venture Bank, and Joint Venture Bank with Private Bank in terms of tools and techniques used for credit risk identification.

\section{KEY WORDS}

Credit risk, Identification, Check list, SWOT, Scenario, Analysis, Simulation, Stress testing

\section{INTRODUCTION}

Credit risk management practice is a prearranged approach to managing uncertainties through risk assessment, analysis, monitoring and developing the strategies to mitigate the risk. The credit risk management strategies basically focus to transferring, avoiding, reducing the negative impacts of the risk. The process of credit risk management has four folds. The first is to understand the risk related to the credit. The understanding of the credit risk is a foundation of the credit risk management process. The second fold is to identify the source of the credit risk, which is to identify the leading factors causing the credit risk. The third fold is an assessment and analysis of the risk. The assessment and analysis is a technique to quantify the risk level entire the certain credit portfolio and individual credit account. The fourth fold is the monitoring and controlling of the credit risk, which is a preventive approach for bank and financial institutions.

Banks develop the general framework of credit risk identification and management to control the risk. For this purpose, various techniques can be applied to different situations, products, 
ISSN: 2362-1303 (Paper) | eISSN: 2362-1311(Online)

JOURNAL OF ADVANCED ACADEMIC RESEARCH (JAAR)

July 2015

portfolio, and individual borrower. It is fundamental for banks to have a comprehensive risk management framework as there is a growing realization that sustainable growth seriously depends on the development of a comprehensive risk management framework (Greuning \& Bratanovic, 2003). The general framework of risk identification and management is developed; techniques can be applied to different situations, products, instruments and institutions (Gakure, Ngugi, Ndwiga, \& Waithaka, August 2012, p. 222).

In today's fast-moving banking business environment, banks are exposed to a large number of credit portfolios. In the same manner, banks face various types of credit related risk during the credit management process. Due to the negative effects of the risks, efficient and effective risk identification tools are required for the sound management system. Risk management is one of the basic tasks to be done, once it has been identified the risk and its factors of the borrowers. The heart of good risk management is the identification and handling of risks. Its aim is to enhance maximum sustainable value to all the activities of the banks.

Risk management in the financial sector is very significant that all sectors of the economy. As the main objective of the institution is to maximize revenues and offer the maximum value to the shareholder. Therefore, risk management is essential to achieve the goal of wealth maximization (Al-Tamimi \& Al-Mazrooei, 2007). Hence, Credit risk management is a structured approach to managing uncertainties through risk assessment, development of strategies to manage it and mitigation of risk using executive resources. . The strategies include transferring to another party, avoiding the risk, reducing the negative effects of the risk, and accepting some or all of the consequences of a particular risk (Afriyie \& Akotey, 2012, p. 1).

Risk management as a technical discipline has become a standard area of business practice in recent years. Robust risk management practices in the banking sector are important for both financial stability and economic development. The development of adequate capacity to measure and manage risks is also important for banks to effectively perform their roles in financing economic activities, most especially the task of continuously providing credit to a large number of enterprises whose activities underpin economic growth. Risk management is the identification, assessment and analysis of risk. It also focuses on coordinating the application of resources to minimize, monitor, and control the probability and/or impact of unfortunate events or to maximize the realization of opportunities.

The present paper discusses and analyses the current practices in credit risk identification of commercial banks of Nepal. It focuses the tools and methods used in credit risk identification process during credit appraisal by Nepalese commercial banks. This is the first published attempt to study empirically the credit risk identification techniques followed by the Nepalese commercial banks.

\section{PURPOSE OF THE STUDY}


ISSN: 2362-1303 (Paper) | eISSN: 2362-1311(Online)

JOURNAL OF ADVANCED ACADEMIC RESEARCH (JAAR)

July 2015

The study will analyses the various credit risk identification techniques followed by the commercial banks during the risk management process. This study focuses on various techniques of credit risk identification practiced by the commercial banks. So, that it will be useful for top management of the banks. The study will present different practices which can be shared by many commercial banks in the banking industry.

Finally, the study will contribute to the broader realm of banking business and academic research. In the banking business, through its recommendations, the study will add value to better credit management practices in the Nepalese banking sector. In the academic world, the study will add value to academic research in the broader area of credit risk management.

\section{STATEMENT OF PROBLEM}

Credit risk management practices are an issue of concern in financial institutions today and there is need to develop improved processes and systems to deliver better visibility into future performance. There have been controversies among researchers on the effect of credit management techniques adopted by various institutions. According to Saunders and Cornett (2002), good selection strategy for risk monitoring is adopted by the credit unions implies good pricing of the products in line with the estimated risk which greatly affect their profitability. On the other hand it is stated that loan portfolio management and operational efficiency management are the most important to consider in CRM as they are the most important in enhancing the quality lending. Hence, the principal concern of this study is to ascertain the various credit risk identification techniques and tools that are adapted by commercial banks on their credit management practices.

\section{OBJECTIVE OF THE STUDY}

The main objective of the study is to analyze the credit risk identification techniques practiced of some selected commercial banks operating in Nepal. The key objective of this research is to ascertain differences between States owned Private sector and Joint venture bank's practices of credit identification techniques in the credit process.

\section{HYPOTHESIS OF THE STUDY}

To fulfill the above objective of the study, the following hypotheses were developed and tested by using statistical tools.

$\mathrm{H}_{1}$ : There are significances differences of credit risk identification technique followed by the commercial banks. 
ISSN: 2362-1303 (Paper) | eISSN: 2362-1311(Online)

JOURNAL OF ADVANCED ACADEMIC RESEARCH (JAAR)

$\mathrm{H}_{1.1:} \quad$ There are significances differences of credit risk identification technique followed by the State owned and Private sector.

$\mathrm{H}_{1.2:} \quad$ There are significances differences of credit risk identification technique followed by the State owned and Joint venture bank.

$\mathrm{H}_{1.3}$ : There are significances differences of credit risk identification technique followed by the Private sector and Joint venture bank.

\section{METHODOLOGY}

In order to find answers to the research questions useful different methods and instruments were used to collect data. The researcher has chosen the survey as the appropriate research design for the study, and as such, questionnaires were used as research instruments. A sample of 9 commercial banks randomly chosen was used in this analysis. Fourteen questionnaires were used to gather data with about three categories of banks like State owned, Private sector and Joint venture banks chosen. Descriptive statistics and ANOVA used to analyze the data.

\section{LITERATURE REVIEW}

Credit risk management in bank and financial institutions attracted by several researchers; within the few years, a number of studies have provided the regulation into the practice of credit risk management within the bank and financial institution. The following is an attempt to summarize the main conclusions of some selected studies.

Oldfield and Santomero (1997) posited that risk facing all financial institutions can be segmented into three separate types from a management perspective. These are (i) risk that can be eliminated or avoided by simple business practices (ii) risk that can be transferred to other participants and (iii) risk that must be actively managed at the firm level.

Santomero (1997) reviewed and evaluated financial risk management systems in a number of North American banks and a few outside of America. He examined both the philosophy and practice of financial risk management. The writer acknowledged that the sophistication of the risk management techniques varies according to the size of the bank. Those at the higher end tend to utilize more advanced and technical risk management techniques. He stated that "best practice" as opposed to "average practice". The main findings of the study are as follows: credit risk techniques need to be standardized not only across borrowers but across institutions as well; credit losses need to be closely monitored but systems are not adequate to track the activity; interest rate risk gap management has improved, however the use of book value accounting should be replaced with market value accounting; simulation currently in use is perceived as rather simple and needs to incorporate dynamic hedging techniques that are used 
ISSN: 2362-1303 (Paper) | eISSN: 2362-1311(Online)

JOURNAL OF ADVANCED ACADEMIC RESEARCH (JAAR)

July 2015

in other fixed income models; despite the fact that VAR (value at risk) is a fantastic tool many banks are still using ad hoc approaches in order to determine foreign exchange and other trading limits; crisis models need to be linked to operational factors; illiquidity risk should be defined and built into the illiquid positions, and off-balance sheet risk should be integrated more into the overall decision making process.

Crouhy, Galai, \& Mark (2000), reviewed the current proposed industry sponsored Credit Value-at-Risk methodologies. Firstly, the credit migration approach, as proposed by JP Morgan with Credit Metrics, is based on the probability of moving from one credit quality to another, including default, within a given time horizon. Secondly, the option pricing, or structural approach, as initiated by KMV and which is based on the asset value model originally proposed by Merton (Merton, R., 1974). They argue that in this model the default process is endogenous, and relates to the capital structure of the firms. Default occurs when the value of the firm's assets falls below some critical level. Thirdly, the actuarial approach as proposed by Credit Suisse Financial Products (CSFP) with CreditRisk+ and which only focuses on default. Default for individual bonds or loans are assumed to follow an exogenous Poisson process. Finally, McKinsey proposes Credit Portfolio View which is a discrete time multi-period model where default probabilities are conditional on the macro-variables like unemployment, the level of interest rates, the growth rate in the economy, which to a large extent drive the credit cycle in the economy.

In the review of Sinkey (2002), modern risk management in the banking sector can be highlighted by five points and these are; identification of risk, measure, risk based pricing, monitor and control. This process of risk management is very much important to the commercial banking industry since most of their clients are vulnerable to co-variant risk, market risk and credit risk.

Bagchi (2003) examined the credit risk management in banks in India. He examined risk identification, risk measurement, risk monitoring, and risk control and risk audit as basic considerations for credit risk management in banks. The author concluded that the proper credit risk structural design, policies, procedures and framework of credit risk management, credit rating system, monitoring and control contributes to success of credit risk management system in the banking industry.

Bandyopadhyay (2006) conducted the research on the probability of default of Indian corporate bonds with logistic and $Z$-score model approaches. The author concluded that by using ' $Z$ ' score model, banks and investors in emerging markets like India can get early warning signals about the firm's solvency status and reconsider the magnitude of the default premium require on low grade securities. The PD estimate from logistic analysis would help banks to estimate credit risk capital and set corporate pricing on a risk adjusted return basis. This model has high 
ISSN: 2362-1303 (Paper) | eISSN: 2362-1311(Online)

JOURNAL OF ADVANCED ACADEMIC RESEARCH (JAAR)

July 2015

classification power of sample and high prediction power in terms of its ability to detect bad the firm in the sample.

Bodla \& Verma (2009) examined the credit risk management framework of Indian commercial banks. The study was based on a sample of 26 SCBs comprising 18 PSBs, eight private sector banks and a foreign bank. This sample of 26 banks was made up of 19 small banks and seven large banks The results show that the authority for approval of Credit Risk with 'Board of Directors' in case of $94.4 \%$ and $62.5 \%$ of the public sector and private sector banks, respectively. The survey has brought out that irrespective of sector and size of bank, Credit Risk Management framework in India is on the right track and it is fully based on the RBI's guidelines issued in this regard

Disbuda (2010), investigated the relationship between credit market development and economic growth in Turkey over the period of 1961-2008 using an ARDL-Bounds testing approach. The empirical results indicate that credit market development has a positive effect on economic growth until the period of the over-finance in Turkey. He suggested that the bank credit to play 'supply-leading' role it is necessary to regulate financial markets effectively and efficiently.

Savvides (2011) emphasized the need for a coherent and multidisciplinary methodology in the assessment of credit risk in bank lending. He argued that credit risk should be assessed in the only context that is possible, which is through cash flow projections generated by sound and methodologically correct financial models which also accommodate the calculation of the margins of uncertainty in the projections by allowing Monte Carlo simulation software to calculate the impact of probable supposition. Moreover, within this framework where the borrower risk and financing structure phases are drafted out, it is possible to both identify and evaluate the impact of various risks and arrangement of appropriate financing solutions in the loan contract. He addressed that the result of this approach to corporate lending would be to reduce credit risk, and to contain the effects of a default on the lending institution.

Thiagarajan, Ayyappan, \& Ramachandran (2011), empirical studied carried out to predict the determinants of the credit risk in the Indian commercial banking sector by using an econometric model. They utilized a panel data model at the bank level for 22 public sector banks and 15 private sector banks, shown some unique determinants of the credit risk in the Indian commercial banking industry. The model used in the study has a high R square for both public and private sector banks which is a reflection of the fitness of the model and its inevitability. The results explained that the lagged nonperforming assets had a strong and statistically significant positive influence on the current non-performing assets. There is a significant inverse relationship between the GDP and the credit risk for both public and private 
ISSN: 2362-1303 (Paper) | eISSN: 2362-1311(Online)

JOURNAL OF ADVANCED ACADEMIC RESEARCH (JAAR)

July 2015

sector banks. The study revealed that both macroeconomic and bank specific factors play crucial role in determining the credit risk of the commercial banking sector.

Alam \& Masukujjaman (January-June, 2011), examined the risk management practices of commercial banks in Bangladesh based on five commercial banks operating in Bangladesh. Primary data were used to collect the information through questionnaires with five points Likert scales. The objective of the research was to critically examine risk management practices of Bangladeshi banks, i.e., types of risk facing a bank, procedure and techniques used to minimize the risk, etc. The study also examined how far the banks follow the guidelines of Bangladesh Bank regarding risk management. The research revealed that credit risk, market risk and operational risk are the major risks in commercial banks, which are managed through three layers of management system. The Board of Directors performs the responsibility of the main risk oversight, the Executive Committee monitors risk and the Audit Committee oversees all the activities of banking operations. In the circumstance of opinions regarding use of risk management techniques, it was found that internal rating system and risk adjusted rate of return on capital are relatively more important techniques used by commercial banks in Bangladesh.

Nazir, Daniel, \& Nawaz (2012) examined and compared the risk management practices of Conventional and Islamic banks in Pakistan. The result found that those Pakistani banks are efficient in credit risk analysis, risk monitoring and understanding the risk in the most significant factors of risk management. Moreover, there is significant difference in risk management practices of the Islamic and conventional banks of Pakistan.

Abdelrahim (May 2013) conducted the research on effectiveness of credit risk management of Saudi bank in light of global financial crisis with the objective of examine the determinants, challenges and developing means of credit risk managements. The methodology was descriptive and analytical used "CAMEL"Model for analyzing performance of credit risk management. The study concluded that liquidity has a significantly positive impact beside bank size, which had significantly negative impact on effectiveness of credit risk management. While other variables of capital adequacy, asset quality, management soundness and earning had an insignificant impact on the effectiveness of credit risk management. The effectiveness credit risk management facing challenge were: weak corporate governance, low quality of assets, little landing diversification; lack of serious financial analysis; not charging a risk premium on risky loans, corruption by credit staffs; priority of profitability at the expense of safety and priority of loan guarantees at expense of capacity of repayment. Means of developing the effectiveness of credit risk management in sequent importance were: training of credit staffs; improving assets quality; strengthening corporate governance; professional analysis of customer's financial position and having access to Credit Information Centre. The study recommended that an overall strategy for effective credit risk management of Saudi Banks based on enhancing capital adequacy, upgrading asset quality, intensification Vol. 2. No. II www.phdcentre.edu.np 
ISSN: 2362-1303 (Paper) | eISSN: 2362-1311(Online)

JOURNAL OF ADVANCED ACADEMIC RESEARCH (JAAR)

July 2015

management soundness, increasing earnings, having adequate liquidity and reducing sensitivity to market risk besides hedging credit risk; having adequate provisions for downgraded loans; renegotiating loan terms and conditions, transferring credit risk to a third party, extending credit maturity by rescheduling and lowering interest rate on insolvent loan.

Wood \& Kellman ( 2013) examined the risk management practices of Barbadian Banks with the primary objective to evaluate the various types of risk faced by banks operating in Barbados. Information was obtained via an interview survey of Senior Bank personnel in 2011. The survey covered key aspects of risk management, including the importance of risk management practices, risk identification, risk monitoring and nature of risk management practices. The main findings of the study are: risk managers perceive risk management as critical factors to banks' performance; the types of risks causing the extreme exposures are credit risk, operational risk, country or sovereign risk, interest rate risk and market risk; there was a high level of success with current risk management practices and these practices have evolved over time in line with the changing economic environment and regulatory updates. Overall, the findings suggest strongly that in light of the depressed economic climate, banks operating in Barbados were certainly risk-focused for mitigation purpose.

\section{RESULT AND DISCUSSION}

This section presents the findings obtained from the questionnaire survey. These results will be exposed in nine sub-sections: interview technique, Root cause effect, Checklist Analysis, SWOT Analysis, Scenario Analysis, Expert Judgment, Simulation, Stress Testing and credit risk identification practices.

\subsection{Interview Technique for Credit Risk Identification}

Table no. 1 shows that the practices of respondents regarding the interview technique to identify the credit risk in their banks. Out of 380 respondents, $66.1 \%(n=251)$ are frequently using the interview method for credit risk identification during the credit analysis. Similarly, $13.7 \%(n=52)$ was not used the method, although identifying the credit risk.

Table no. 1 Frequency of Interview Technique

\begin{tabular}{|c|c|c|c|c|c|}
\hline & Strongly use & Use & Neutral & Not use & Total \\
\hline Frequency & 55 & 251 & 22 & 52 & 380 \\
\hline Percent & 14.5 & 66.1 & 5.8 & 13.7 & 100 \\
\hline \multicolumn{6}{|c|}{ Chi-Square } \\
\hline \multicolumn{7}{|c|}{ Value } & df & Asymp. Sig. (2-sided) \\
\hline \multicolumn{2}{|c|}{ Pearson Chi-Square } & 528.079 & 4 & \multicolumn{2}{c|}{0.000} \\
\hline
\end{tabular}

Sources: Field survey, 2014

Vol. 2. No. II

www.phdcentre.edu.np 
ISSN: 2362-1303 (Paper) | eISSN: 2362-1311(Online)

JOURNAL OF ADVANCED ACADEMIC RESEARCH (JAAR)

July 2015

This table indicates that the calculated value of the chi-square statistics was 528.079 at 4 degree of freedom. The significance value (p) associated with the data was 0.00 , that was less than the threshold value 0.05 . Hence, Interview technique is not equally followed by the commercial banks for credit risk identification.

\subsection{Root Cause Effect for Credit Risk Identification}

Table no. 2 demonstrates the views of the respondents on the practices of root cause analysis as a credit identification tool in their organization. Out total respondents $17.1 \% \quad(n=65)$ respondents was strongly use root cause techniques during the credit risk identification process. $20 \%(n=56)$ respondents were in neutral to understand their view. 32.4\% $(n=132)$ respondents were not used this technique in their organization. This result seems that majority of the respondents were not adopted root cause analysis as a credit risk identification technique.

Table no. 2 Frequency of Root Cause Technique

\begin{tabular}{|c|c|c|c|c|c|}
\hline & Strongly use & Use & Neutral & Not use & Total \\
\hline & 65 & 116 & 76 & 123 & 380 \\
\hline Frequency & 17.1 & 30.5 & 20 & 32.4 & 100 \\
\hline Percent & \multicolumn{3}{|c|}{ Chi -Square } \\
\hline \multicolumn{3}{|c|}{ Value } & df & \multicolumn{3}{c|}{ Asymp. Sig. (2-sided) } \\
\hline Pearson Chi-Square & 26.168 & 3 & \multicolumn{3}{c|}{0.000} \\
\hline
\end{tabular}

Sources: Field survey, 2014

This table indicates that the calculated value of the chi-square statistics was 373.789 at 4 degrees of freedom. The significance value (p) associated with the data was 0.00 , which was less than the threshold value 0.05. Hence, Root cause analysis technique is not absolutely adopted as the credit risk identification tools by the banks.

\subsection{Checklist Analysis and for Credit Risk Identification}

Table no. 3 reveals the views of the respondents in the practice of check list analysis as a credit identification instrument in their banks. Out total respondents, $11.6 \%(n=44)$ respondents were strongly used check list analysis techniques during the credit risk identification process. $48.9 \%$ $(\mathrm{n}=186)$ respondents normally used this technique in credit risk identification process. $1.1 \%$ $(n=4)$ respondents were in neutral to recognize their view. 37.9\% $(n=144)$ respondents were not use check list analysis as credit risk identification technique. This result illustrates that majority of the respondents were implement check list analysis as a credit risk identification technique. 
ISSN: 2362-1303 (Paper) | eISSN: 2362-1311(Online)

JOURNAL OF ADVANCED ACADEMIC RESEARCH (JAAR)

Table no. 3 Frequency of Root Cause Technique

\begin{tabular}{|c|c|c|c|c|c|c|}
\hline & Strongly use & Use & Neutral & Not use & Not at all & Total \\
\hline Frequency & 44 & 186 & 4 & 144 & 2 & 380 \\
\hline Percent & 11.6 & 48.9 & 1.1 & 37.9 & 0.5 & 100 \\
\hline \multicolumn{6}{|c|}{ Chi -Square } \\
\hline \multicolumn{2}{|c|}{ Value } & df & \multicolumn{3}{c|}{ Asymp. Sig. } \\
\hline \multicolumn{2}{|c|}{ Pearson Chi-Square } & 373.8 & 4 & \multicolumn{3}{c|}{0.000} \\
\hline
\end{tabular}

Sources: Field survey, 2014

This table indicates that the calculated chi-square statistics, for 4 degrees of freedom, is 373.789. Additionally, it indicates that the significance value (0.000) is less than the usual threshold value of 0.05 . The result indicates that all sample banks have not same practice of root cause techniques to identify the credit risk in their organization.

\subsection{SWOT Analysis and for Credit Risk Identification}

Table no. 4 shows the observation of the respondents on the practices of SWOT Analysis as a credit identification tool in their organizations. Out total of 380 respondents, 68.2\% $(n=259)$ respondents were strongly used SWOT analysis techniques during the credit risk identification process. Remaining $31.8 \%(\mathrm{n}=121)$ respondents used this technique in their organization. This outcome seems that all respondents were adopting the SWOT analysis as a credit risk identification technique.

Table no. 4 Frequency of SWOT Analysis

\begin{tabular}{|c|c|c|c|}
\hline & Strongly use & Use & Total \\
\hline Frequency & 259 & 121 & 380 \\
\hline Percent & 68.2 & 31.8 & 100 \\
\hline \multicolumn{4}{|c|}{ Chi-Square } \\
\hline \multicolumn{5}{|c|}{ Value } & df & Asymp. Sig. \\
\hline Pearson Chi Square & 50.166 & 1 & 0.000 \\
\hline
\end{tabular}

Sources: Field survey, 2014

This table points out that the calculated value of the chi-square statistics was 50.116 at 1 degree of freedom. The significance value (p) associated with the data was 0.00 , that was less than the threshold value 0.05. The result indicates that all sample banks have not used the SWOT analysis techniques to identify the credit risk during the risk management process.

\subsection{Scenario Analysis and for Credit Risk Identification}

Scenario analysis in credit management is the process of scheming and predicting the value of an investment under a variety of different situations, or scenarios. These scenarios can range from very likely to incredible, but still possible. For each scenario, the bank or analyst 
ISSN: 2362-1303 (Paper) | eISSN: 2362-1311(Online)

JOURNAL OF ADVANCED ACADEMIC RESEARCH (JAAR)

July 2015

considers historical data and the chain of events that will cause the factors in that scenario to impact the banking business.

Table no. 5 exposes the views of the respondents in the practice of Scenario analysis as a credit identification tool in their banks. Out total 380 respondents, $43.1 \%(n=164)$ respondents were strongly used Scenario analysis during the credit risk identification process. $52.6 \%(\mathrm{n}=200)$ respondents normally used this technique in credit risk identification process. Remaining $4.3 \%$ $(n=15)$ respondents have not used Scenario analysis as a credit risk identification technique. This result illustrates that most of the respondents were executed Scenario analysis as a credit risk identification technique.

Table no. 5 Frequency of Scenario Analysis

\begin{tabular}{|c|c|c|c|c|c|}
\hline & Strongly use & Use & Not use & Not at all & Total \\
\hline Frequency & 164 & 200 & 12 & 4 & 380 \\
\hline Percent & 43.2 & 52.6 & 3.2 & 1.1 & 100 \\
\hline \multicolumn{7}{|c|}{ Chi-square } \\
\hline \multicolumn{7}{|c|}{ Value } & df & \multicolumn{2}{c|}{ Asymp. Sig. } \\
\hline \multicolumn{2}{|c|}{ Pearson Chi Square } & 325.853 & 3 & \multicolumn{2}{c|}{0.000} \\
\hline
\end{tabular}

Sources: Field survey, 2014

This table indicates that the calculated value of the chi-square statistics was 325.853 at 3 degrees of freedom. The significance value (p) associated with the data was 0.00 , which was less than the threshold value 0.05 . The result indicates that the practice of the scenario analysis technique is a significantly difference in sample banks during the credit processing.

\subsection{Expert Judgment for Credit Risk Identification}

Expert judgment is used for predicting the occurrence of future events and the consequences of decisions regarding the credit risk identification.

Table no. 6 Frequency of Expert Judgment

\begin{tabular}{|c|c|c|c|}
\hline & Strongly use & Use & Total \\
\hline Frequency & 42 & 338 & 380 \\
\hline Percent & 11.1 & 88.9 & 100 \\
\hline \multicolumn{4}{|c|}{ Chi-square } \\
\hline & Value & df & Asymp. Sig. \\
\hline Pearson Chi-Square & 230.568 & 1 & 0.00 \\
\hline
\end{tabular}

Sources: Field survey, 2014

Table no. 6 shows the observation of the respondents on the practices of Expert judgment as a credit identification tool in their organizations. This outcome seems that expert judgment was used by almost respondents as a credit risk identification technique. This table indicates that the calculated value of the chi-square statistics was 230.568 at 1 degree of freedom. The Vol. 2. No. II 
ISSN: 2362-1303 (Paper) | eISSN: 2362-1311(Online)

JOURNAL OF ADVANCED ACADEMIC RESEARCH (JAAR)

July 2015

significance value (p) associated with the data was 0.00 , which was less than the threshold value 0.05 . The result shows that the practice of the expert judgment technique is a significantly difference in sample banks during the credit processing.

\subsection{Simulation for Credit Risk Identification}

Simulation is a risk measuring technique adopted by the different modeling process. Table no. 7 presents the views of the respondents in the practice of simulation method as a credit identification instrument in their banks. Out total 380 respondents, $1.1 \%(\mathrm{n}=4)$ respondents were strongly used Simulation method during the credit risk identification process. $26.6 \%$ $(\mathrm{n}=101)$ respondents normally used this technique in credit risk identification process. $21.6 \%$ $(\mathrm{n}=82$ respondents were in neutral to recognize their view. $36.1 \%(\mathrm{n}=137)$ respondents were not using this method as a credit risk identification technique. This result illustrates that the majority of the respondents was not using this method for credit risk identification.

Table no. 6 Frequency of Expert Judgment

\begin{tabular}{|c|c|c|c|c|c|c|}
\hline & Strongly use & Use & Neutral & Not use & Not at all & Total \\
\hline Frequency & 4 & 101 & 82 & 137 & 56 & 380 \\
\hline Percent & 1.1 & 26.6 & 21.6 & 36.1 & 14.7 & 100 \\
\hline \multicolumn{3}{|c|}{ Chi -Square } \\
\hline \multicolumn{2}{|c|}{ Vearson Chi-Square } & 131.132 & 4 & \multicolumn{3}{c|}{ Asymp. Sig. } \\
\hline
\end{tabular}

Sources: Field survey, 2014

This table indicates that the calculated chi-square statistics, for 4 degrees of freedom, is 131.132. Additionally, it indicates that the significance value $(0.000)$ is less than the usual threshold value of 0.05 . The result shows that the practice of the simulation technique is a significant difference in sample banks during the credit processing.

\subsection{Stress Test for Credit Risks Identification}

Stress testing is a risk identification technique in the banking sector. It focuses basically on credit risk, market risk and liquidity risk to the financial health of the banks. The results of stress tests depend on the assumptions made in various economic scenarios of the banking market. The purpose of the test is to determine capital of the bank to cope risky area. 
ISSN: 2362-1303 (Paper) | eISSN: 2362-1311(Online)

JOURNAL OF ADVANCED ACADEMIC RESEARCH (JAAR)

Table no. 7 Frequency of Stress Test

\begin{tabular}{|c|c|c|c|c|c|}
\hline & Strongly use & Use & Neutral & Not use & Total \\
\hline Frequency & 7 & 216 & 70 & 87 & 380 \\
\hline Percent & 1.8 & 56.8 & 18.4 & 22.9 & 100 \\
\hline \multicolumn{2}{|c|}{ Chi -Square } & & \multicolumn{2}{c|}{ Asymp. Sig. } \\
\hline \multicolumn{2}{|c|}{ Value } & df & \multicolumn{2}{c|}{0} \\
\hline
\end{tabular}

Sources: Field survey, 2014

Table no. 7 exposes the views of the respondents in the practice of the Stress test as a credit identification tool in their banks. Out total 380 respondents, $1.8 \%(\mathrm{n}=7)$ respondents strongly used Stress test during the credit risk identification process. 56.8\% $(\mathrm{n}=216)$ respondents normally used this technique in credit risk identification process. $18.4 \%(\mathrm{n}=70)$ respondents were stood neutrally on giving views. Remaining $22.9 \%(\mathrm{n}=87$ ) respondents have not used this test as credit risk identification technique. This result illustrates that the majority of the respondents performed Stress test as a credit risk identification technique.

This table indicates that the calculated value of the chi-square statistics was 242.884 at 3 degrees of freedom. The significance value (p) associated with the data was 0.00 , which was less than the threshold value 0.05 . The result shows that the practice of the stress testing is a significant difference in sample banks during the credit processing.

\subsection{Commercial and Credit Risk Identification}

Table no 8. Descriptive Statistics

\begin{tabular}{|c|c|c|c|c|c|c|c|c|}
\hline & \multirow{2}{*}{$\begin{array}{c}\text { Bank } \\
\text { Class }\end{array}$} & $\mathrm{N}$ & Mean & \multirow{2}{*}{$\begin{array}{c}\text { Std. } \\
\text { Deviation }\end{array}$} & \multirow{2}{*}{$\begin{array}{c}\text { Std. } \\
\text { Error }\end{array}$} & & & \multicolumn{2}{|c|}{$\begin{array}{l}\text { 95\% Confidence } \\
\text { Interval for Mean }\end{array}$} & \multirow{2}{*}{ Minimum } & \multirow{2}{*}{ Maximum } \\
\cline { 6 - 9 } & & & & $\begin{array}{c}\text { Lower } \\
\text { Bound }\end{array}$ & $\begin{array}{c}\text { Upper } \\
\text { Bound }\end{array}$ & & \\
\hline PSB & 57 & 31.0175 & 2.58769 & 0.34275 & 30.3309 & 31.7041 & 22 & 37 \\
\hline JVB & 72 & 22.3611 & 6.72248 & 0.79225 & 20.7814 & 23.9408 & 17 & 35 \\
\hline SOB & 251 & 36.4861 & 4.35095 & 0.27463 & 35.9452 & 37.0269 & 26 & 49 \\
\hline Total & 380 & 32.9895 & 7.21695 & 0.37022 & 32.2615 & 33.7174 & 17 & 49 \\
\hline
\end{tabular}

$\mathrm{PSB}=$ Private sector bank, JVB=Joint venture bank, $\mathrm{SOB}=$ State owned bank

Sources: Field survey 2014,

Credit risk identification techniques used by the group of commercial banks $\mathrm{F}(2,377)$ $=258.933, \mathrm{p}<0.05$. More techniques adopted by the State owned bank $(\mathrm{m}=36.4861)$, less

Vol. 2. No. II

www.phdcentre.edu.np 
ISSN: 2362-1303 (Paper) | eISSN: 2362-1311(Online)

JOURNAL OF ADVANCED ACADEMIC RESEARCH (JAAR)

techniques used by Private sector bank $(\mathrm{m}=3.10175)$. Similarly, Joint venture banks used least techniques, i.e. $(\mathrm{m}=22.3611)$ comparison of state owned banks and joint venture banks.

Table no. 9 Test of Homogeneity of Variance

\begin{tabular}{|c|c|c|c|}
\hline Levene Statistic & df1 & df2 & Sig. \\
\hline 58.538 & 2 & 377 & 0 \\
\hline
\end{tabular}

Sources: Survey 2014

Table no. 9 provides the Levene's statistics to check the assumption that the variances of the three groups of bank have used the credit risk identification techniques in their banks. The result shows that the Levene's test is significant; $F(2,377)=58.538, p=000-$ at the .05 alpha level for three groups of banks. Thus, the assumption of homogeneity of variance is violated. So that Robust test of equality was applied.

Table no.10 Robust Test of Equality Mean

\begin{tabular}{|c|c|c|c|c|}
\hline & Statistic $^{\mathrm{a}}$ & df1 & df2 & Sig. \\
\hline Welch & 183.243 & 2 & 132.058 & 0 \\
\hline Brown-Forsythe & 234.345 & 2 & 120.988 & 0 \\
\hline
\end{tabular}

Sources: Field Survey 2014,

In table no. $10 \mathrm{p} \leq 0.05$, we concluded that reject the null hypothesis and concluded that at least two groups means significantly different from each other.

Table no. 11 ANOVA

\begin{tabular}{|c|c|c|c|c|c|}
\hline & $\begin{array}{c}\text { Sum of } \\
\text { Squares }\end{array}$ & df & $\begin{array}{c}\text { Mean } \\
\text { Square }\end{array}$ & F & Sig. \\
\hline Between Groups & 11423.66 & 2 & 5711.832 & 258.933 & 0 \\
Within Groups & 8316.295 & 377 & 22.059 & & \\
Total & 19739.96 & 379 & & & \\
\hline
\end{tabular}

Source: survey 2014

Since there is a difference in means, including the standard deviation (because of the violation of the assumption of homogeneity of variance) among three groups, we followed Robust Tests of equality of means. The Anova table showed there was a significant difference $(p<.05)$ among either one or all of them.

Likewise, one-way Anova was carried out between Identification of credit risk with class of Bank. This credit risk was about whether the concerned employees in the bank used tools and techniques to identify the risk associated with elements in a credit application form. Due to violation of homogeneity, we calculated robust Test for equality of variance that also proved significant $(\mathrm{p}<.05)$. The Anova model was significant $(\mathrm{p}<.05)$ with $\mathrm{F}$ value of 258.98 at 2 degrees of freedom, letting us know at least one significant difference do exist. The null Vol. 2. No. II 
ISSN: 2362-1303 (Paper) | eISSN: 2362-1311(Online)

JOURNAL OF ADVANCED ACADEMIC RESEARCH (JAAR)

July 2015

hypotheses Ho can be rejected in favor of the alternative hypothesis. It revealed that there was a significant difference between all three categories of bank, namely State-Owned bank with Private Bank, State-Owned bank with Joint Venture Bank and, Joint Venture Bank with Private bank in terms of tools and techniques of credit risk identification in their organization.

\section{CONCLUSION}

The main objective of the study is to analyze the credit risk identification techniques practiced of some selected commercial banks operating in Nepal and the specific objectives were to examine the To ascertain differences between States owned Private sector and Joint venture bank's practice of credit identification techniques in the credit process. The results of the study indicate that the Nepalese bankers are aware of the importance of various techniques to effectively identify the risk level. Furthermore, the Nepalese commercial banks have used various techniques like an interview, root cause effect, check list analysis, SWOT analysis, scenario analysis, expert judgment, simulation, stress testing, etc. Basically, banks have adopted frequently qualitative approach like an interview with borrowers, SWOT analysis, and scenario analysis as credit risk identification tools. But the bank was not a familiar about quantitative approach likes simulation models and stress testing in regular practices in their credit appraisal. The evidences concluded that the banking industry is less concentrated to use the modern credit identification techniques. In this regard, the bank must closely follow the current developed models to identify the credit risk during the credit assessment. In the assessment processes the banks will determine any deceitful activities on the part of the borrower. The bank is always trying to improve their credit risk identification techniques in their credit policy for quality of lending and various measures are undertaken to follow the effective credit management system.

\section{BIBLIOGRAPHY}

Abdelrahim, K. E. (May 2013). Effectiveness of Credit Risk Management of Saudi Banks in the Light of Global Financial Crisis:A Qualitative Study. Asian Transactions on Basic and Applied Sciences , 3 (2), p 73-90.

Abdullah, A., Khan, A. Q., \& Nazir, N. (July 2012). A Comparative Study of credit Risk management : A Case Study of Domestic and Forign Bank in Pakisthan. Academic Research International , 3 (1), p.371-377.

Alam, M. Z., \& Masukujjaman, M. (January-June, 2011). Risk Management Practices: A Critical Diagnosis of Some Selected Commercial Banks in Bangladesh. Journal of Business and Technology (Dhaka), 6 (1), p15-35. 
ISSN: 2362-1303 (Paper) | eISSN: 2362-1311(Online)

JOURNAL OF ADVANCED ACADEMIC RESEARCH (JAAR) July 2015

Al-Tamimi, H., \& Al-Mazrooei, M. (2007). Banks' Risk Management: A Comparison Study of UAE National and Foreign Banks. The Journal of Risk Finance , 8 (4), p. 394-409.

Aman, Q., \& Zaman, K. (2011). Credit Risk Performance of Private, State Owned and Foreign Banks on the Economy of Pakistan (Econometric Approach). International Research Journal of Finance and Economics (57), p.47-58.

Awojobi, O., \& Amel, R. (2011). Analysing Risk Management in Banks: Evidence of Bank Efficiency and Macroeconomic Impact. Journal of Money, Investment and Banking (22), p 147-162.

Bagchi, S. K. (2003). Credit Risk Management - A Panacea or Conundrum? SBI Monthly Review , 42 (10), p. 497-504.

Bandyopadhyay, A. (2006). Predicting Probability of Default of Indian CorporateBonds: Logistic and Z-Score Model Approaches. The Journal of Risk Finance, 7 ( 3), p. 255 272, http://dx.doi.org/10.1108/15265940610664942.

Bodla, B. S., \& Verma, R. (2009). Credit Risk Management Framework at Banks in India. The Icfai University Journal of Bank Management, , 8 (1), p 47-74.

Chansarn, S. (2008). The Relative Efficiency of Commercial Banks in Thailand: DEA Approach. International Research Journal of Finance and Economics (18), p. 48-58.

Crouhy, M., Galai, D., \& Mark, R. (2000). A comparative analysis of current credit risk models. Finance, Journal of Banking \& Finance (24), p 59-117.

Crouhy, M., Galai, D., \& Mark, R. (2006). The Essentials of Risk Management. USA: McGraw-Hill.

Disbudak, C. (2010). Analyzing the Bank Credit-Economic Growth Nexus in Turkey. European Journal of Economics, Finance and Administrative Sciences (23), p. 34-48.

Gakure, R., Ngugi, J. K., Ndwiga, P. M., \& Waithaka, S. M. (August 2012). Effect of credit risk Management Techniques on the Performance of Unsecured Bank loans Employed Commercial Banks in Kenya. International Journal of Business and Social Research (IJBSR), , 2 (4), p. 221-235.

Greuning, H., \& Bratanovic, S. B. (2003). Analyzing and Managing Banking Risk,A Framework for Assessing Corporate Governance and Financial Risk. Washington, DC.: The World Bank.

Lapteva, M. N. (2009). Credit Risk Management in the Bank. Econimics , 1 (51), 37-38, Availaible on http://vestnik.sseu.ru/view_pdf.php?pdf=2224.

Vol. 2. No. II

www.phdcentre.edu.np 
ISSN: 2362-1303 (Paper) | eISSN: 2362-1311(Online)

JOURNAL OF ADVANCED ACADEMIC RESEARCH (JAAR) July 2015

Nazir, M. S., Daniel, A., \& Nawaz, M. M. (2012). Risk Management Practices: A Comparison of Conventional and Islamic Banks in Pakistan. American Journal of Scientific Research (68), p 14-22.

Oldfield, G., \& Santomero, A. M. (1997). Risk Management in Financial Institutions. Sloan Management Review , 39 (1), p. 33-46.

Oldfield, G., \& Santomero, A. (1997 Summer). The Place of Risk Management in Financial Institutions. Solan Management Review , 1-29.

Santomero, A. (1997). Commercial Bank risk Management : An Analysis of the Process. Journal of Financial Service Research , 12 (2/3), p. 83-115.

Santomero, A. M. (1997). Commercial Bank Risk Management: An Analysis of the Process. (pp. 1-49). The whartan school, University of pennsylvania, Retrived from http://fic.wharton.upenn.edu/fic/papers/95/9511.pdf.

Saunders, A., \& Cornett, M. M. (2002). Financial Institutions Management: A Risk Management Approach. (4, Ed.) New York.: McGraw Hill.

Savvides, S. C. (2011). Corporate Lending and the Assessment of Credit Risk. Journal of Money, Investment and Banking, p 123-128.

Sinkey, J. F. (2002). Commercial Bank and Financial in the Financial-Services Industry, (6, illustrated ed.). Prentice Hall.

Thiagarajan, S., \& Ramachandran, A. (2011). An Empirical Analysis and Comparative Study of Credit Risk Ratios between Public and Private Sector Commercial Banks in India. International Research Journal of Finance and Economics (65), p 82-92.

Thiagarajan, S., Ayyappan, S., \& Ramachandran, A. (2011). Credit Risk Determinants of Public and Private Sector Banks in India. European Journal of Economics, Finance and Administrative Sciences (34), p 147-154.

Tsai, J.-Y., \& Chang, C.-P. (2012). Credit risk based on firm conduct-performance and bank lending decisions: A capped call approach. Journal of Applied Finance \& Banking , 2 (4), p 69-84.

Wood, A., \& Kellman, A. ( 2013). Risk Management Practices by Barbadian Banks. International Journal of Business and Social Research , 3 (5), p. 22-29. 